\title{
Does English Teachers' Intensification in the Modern Islamic Boarding School Affect Their Teaching Performance?
}

\author{
Mohammad Umar Fakhrudin ${ }^{1 *}$ Erna Andriyanti ${ }^{1}$
}

\author{
${ }^{1}$ Yogyakarta State University, Yogyakarta, Indonesia \\ *Corresponding author. Email: mohammadumar.2019@student.uny.ac.id
}

\begin{abstract}
Teachers' intensification has become a concern in these recent years. For English bilingual program teachers, there are duties besides teaching to complete by them such as becoming a coach, dormitory supervisor, and organization supervisor. These demands create an overloaded work for the teachers. Thus, this study is aimed at identifying the impact of Islamic boarding school teachers' workload on their teaching performance quality. A descriptive case study was employed in this study. Then, the data were analysed using the interview to three Islamic boarding school English teachers and added with the researcher's experience. The result shows that bilingual teachers' intensification affected negatively towards English teachers' performance quality.

Keywords: Teachers' Intensification, Bilingual Program, Teaching Performance
\end{abstract}

\section{INTRODUCTION}

Teachers' intensification has become a concern in these recent years. [1] An overloaded teachers' duty has broken the recruitment and retention of the teachers. The growth of education system complexity in this era is becoming a greater pressure for accountability in all aspects of teachers' professional work [2]. Some researchers point out that the extra role, complexity, and tension teachers are coming from the introduced educational reforms [3], [4], [5], [6]. There are several researchers in developed countries who have given a relevant framework like intensification and accountability to illustrate the significant changes found in the teachers' work and in turn their workload.

The increasing works in both quantities (e.g., overloaded works and multitasking) and quality (e.g., changing work condition and reduced autonomy) can significantly affect principals' condition and well-being [7]. This study shows that principals' workload can bring them to excessive work-related stress, burn-out, and mental health issues. In this study, it is explained that if the principals are faced with rising job expectations, they will be more likely to experience role ambiguity, overload, and conflict on a regular basis. [8] Thus, these experiences lead them to stressing occupation, and negatively affect the principals' job satisfaction, specifically those who become new principals.
The concept of teaching workload in modern Islamic boarding schools is not seen from the teachers' regular activities like taking classes, preparing lesson plans, evaluating the scripts, attending programs and conferences. However, the teachers must involve themselves in different activities either academic or nonacademic activities which are done outside of school hours. The activities are being a supervisor of organization, supervisor of multilingual or multilingual room, and official of coach of English competition. Multilingual itself means the ability of someone to speak in three or more languages in which different languages are used actively in daily communication within a multilingual society [9], [10]. It emphasizes on how two or more languages either in written or spoken way be used based on its communicative functions $[11,12]$. In fact, the demands mentioned above become a burden for the teachers causing them not to have enough time to do selfreflection and prepare their classroom management, which is actually a very crucial notion in education. There are students' characteristics, teachers' efficacy, environmental situation, and the achievement standards of students becoming influential factors in classroom management $[13,14,15]$. It goes without saying that to deal with that objective, the teachers should have a good teaching performance. [16] They are i) a clear objective of the lesson as well as the expected outcome, ii) building background by integrating concepts to students background, past learning and key vocabularies, iii) a clear 
structural idea to all students and allows them to have different pathways based on their needs, iv) using a various strategies of questioning to stimulate and encourage students' development of critical thinking, problem solving and performance skill, v) providing an adequate time for the students to give response, vi) employing instructional approaches aimed to meet the needs of diversified learners, and vii) using a well instruction to meet the proficiency level of all the students in a classroom.

\section{METHOD}

The researcher employed a qualitative research in this study. [117] This kind of research is an interpretative research which demands the researcher to get involved with the participants to have a sustained and intensive experience. [18] The aim of qualitative research is to collect the data on the subject of the research to obtain deep insight of the phenomena of interest. Then, the data is analyzed and interpreted descriptively or narratively [19].

This research was conducted in the bilingual program of Islamic Senior High School AL Hikmah 2. The subject of the study was three English teachers who taught in the program. Those three teachers are assumed to have more burden than other teachers since they do not only teach in the classroom but also in the dormitory where the students (santri) stay.

Further, the researcher conducted an observation and interview to collect the data. In this case, the researcher wrote field notes of the teachers' activities either in the classroom or in the dormitory. Moreover, the semi-structured interview was taken to confirm what had been observed, and to provide more detail and historical information from the participants.

Then, to analyze the data, the writer used the stages [20]. They are:

1. Organizing and preparing the data for analysis;

2. Reading through all the data;

3. Beginning detailed analysis with a coding process;

4. Using the coding process to generate a description of setting people as categories or themes for analysis;

5. Advancing how the description and themes will be represented in the qualitative narrative and;

6. Making an interpretation or meaning of the data.

\section{RESULT AND DISCUSSION}

\section{A. Results}

\section{a. Results on interview}

The researcher explored English teachers' workload in the modern Islamic boarding school by conducting interviews with four English teachers. There were six questions related to their performance caused by their workloads. The questions are as follows:

1. How many hours do you teach in a week?

2. Do you have other duties in the school besides teaching? What are they?
3. Do you have other duties outside of the school? What are they?

4. Is there any relationship between workload and teaching performance?

5. If yes. How much does the workload affect teaching performance?

6. How to deal with that?

In this research, the researcher named the English teacher by ET 1, ET 2, ET 3, and ET 4.

1) Teaching hours in a week

The researcher took "a week" as the standard of the period of time in this research since it covered the teachers' workload in every week. Three of four teachers had overloaded hours to teach in a week since they had more than 40 hours. They were ET 1, ET 2, and ET 4 while ET 3 was under 40. ET 1 and ET 4 had the same teaching hours in a week, 56, and ET 3 had fewer hours than them, 44 hours. Meanwhile, ET 3 had 32 hours to teach in a week.

2) Duties in the school beside teaching

Based on the result of the interview, the researcher found that four teachers had similar duties to do in the school. They were English competition coaches and supervisors of English organizations. ET 1, ET 2, and ET 4 had another similar duty, being a committee of school events. Since ET 1 did not stay in the dormitory, she felt a bit burdened with work to do. Her response was as follows.

"There are several duties that need to be done besides teaching. First, she becomes one of the official coaches of English competitions. Being a coach in this school was quite challenging since almost every year the students won the competitions. Moreover, the second duty is that I am trusted to become the committee of school events and supervisor of English organization. Those two duties often take my time, exactly holiday time because most of the activities are held on the weekend that should be my free or family time."

However, among those four teachers, a teacher with the hardest duties was ET 4. Below is the citation of the interview conducted with ET 4.

"Besides being a teacher, I am a vice principal focusing on students' affairs. It means that I take care of all students' documents and organizations in the school. Moreover, I am also the coach of English competition that sometimes the students (boys) ask me to have rehearsal in the night after finishing the dormitory's activities 
until midnight. Further, mostly I am chosen to be the committee of school events."

3) Duties outside of the school

The researcher asked the duties outside of the school to know how the teachers with loaded works in the school are added with other responsibilities. As a result, all teachers had other duties outside of the school. They might be either public or private responsibilities. The result showed that ET 2, ET 3, and ET 4 are becoming multilingual complex supervisors. They stated that the hardest workload was actually being students' supervisor in the complex. Besides being a teacher who is focusing on their language, the respondents also have to pay attention with students' mental physical condition. They need to take care when the students are getting sick and having problems. They mostly have a rest at midnight to control the students in the complex.

It showed how they had different perspectives about the loads to do outside of the school.

4) Relationship between workload and teaching performance

According to the results of the interview, all of them agreed that their workloads had affected their teaching performance. However, they were divided into two that ET 3 felt burdened but still enjoyed, and ET 1, ET 2 and ET 4 felt the workloads affected a lot. Here is the citation of the interviews with ET 1.

"The workloads significantly affect my teaching performance. As I said there are several things I need to do besides teaching. Mostly, I have no time to have self-reflection about what I did before. It seems simple but actually having evaluation is really important for me to create a better condition and performance in teaching. Further, I used to be less enthusiastic in the last or noon hours because of feeling exhausted from the overloaded hours. I usually ask them to write or do assignments. It means that the treatment I give among classes that should be the same is not so. Moreover, the thing which is clearly affected is about administration."

5) The impact of workloads towards teaching performance

From the answer above, the researcher could say that three teachers strongly agreed that workloads impacted negatively towards teaching performance. The three teachers were ET 1, ET 2, and ET 4. The teachers' answers are presented below:

ET 1:

"I cannot be optimal in finishing the administrations that I need to fulfill. The lesson plans that should be different among classes by considering the students' condition and needs, I make them all the same for it is quite difficult to create many lesson plans with the limited time. I said a limited time because I want to be professional. I do not want to bring my school duties to my home since I have many things to do at home as a wife and mother."

ET 2:

"There are many duties I need to do every day. Sometimes, I get bored and exhausted with all those activities. As you know that I live with and take care of them for 24 hours. I am not only becoming a teacher for them, but also a parent, an old sister, and sometimes a friend. It is not something easy to be multiple roles with all my workloads in the school. I can say that it sufficiently affects my teaching performance since the quality of teaching or treatment among classes will be different when I am tired. I think that is the most terrifying effect of the workload besides the administrative things."

ET 4:

"With all responsibilities I must do, I have to say that I am not a good teacher for my students since I have a very limited time to have self-evaluation and handle the administrative things especially lesson plans."

6) To deal with the workloads

Based on the data obtained from their responses, mostly they answered the way to deal with the workload was time management. The researcher quoted the answer as follows:

ET 1:

"As I told you just now, I tried to be professional. As tiring as my day, I never leave my class even though I am not always in spirit in the class. I have been trying to manage my time well to be able to handle all my duties. To make it efficient but not really effective, I make the materials all the same with the same method or approaches for all classes. Besides that, when I am getting exhausted and hectic with all activities $I$ have, willy nilly I give them many assignments with a short explanation." ET 2:

"Not much that I can do. I try to be happy with the things I must do. Further, I always try to be professional with time management because once I forget, I will leave many things. To make it easier to do those activities is by mapping what to do. It helps me so 
much. Hence, I am still able to have self-reflection."

ET 3:

"Since teaching in the class is already well-organized, I did not feel my workloads outside of teaching are affecting much towards my teaching performance. Further, I guess my duty is not that much, so I still really enjoy my activities."

ET 4:

"To deal with that, I try to make and arrange the schedule every single day in order that all businesses are still handled well even if not very optimal."

\section{b. Results on observation}

To support the data, the researcher also conducted an observation to the field. He found that there were several activities that the bilingual teachers had to do in the bilingual rooms.

1. Tuesday and Friday Night Performance Every Tuesday and Friday night, students had an event named Golden Night and Silver Night. The event made several students perform in order to train their public speaking skills. The performances are English drama, speech, storytelling, debate, and quickey mackey. To have a good performance, the students invited their bilingual supervisor to be the judges that would give several feedbacks at the end of performance.

In this activity, students would be given certain time based on their performance. When the researcher conducted the observation, there were four performances that were divided into two individual performances and two group performances. The two individual performances were speech and storytelling while two other which were group performances were drama and story train. After the pointed students had performed, the masters of ceremony gave the time to the supervisors/teachers to give feedback.

2. Health care and parents' customer service

Based on the observation, another duty to take over by the bilingual teachers is taking care of the students' health and of their development to be reported to their parents. The researcher saw that there is a room called Balai Pengobatan Santri located in the center of the students' rooms. When the researcher visited the room, he found there were more than five students sick with different illnesses. In this case, the supervisors needed to check students' condition every morning, afternoon, and evening. The supervisors were helped by the students in charge of the health and hygiene.

\section{B. Discussion}

This study focused on identifying the relationship between Islamic boarding school English teachers' workload with their teaching performance. The respondents' responses believed that intensification influenced negatively to the quality of teaching because teachers do not have sufficient time to have self-evaluation and preparation to teach. There are three points highlighted based on the findings above.

Firstly, the researcher tried to know about the teaching hours of each teacher. It was found that from four respondents, there were three teachers that had more than 40 hours, and only one teacher had less than 40 hours in a week. The first and the fourth respondents stated that they taught for 56 hours in a week which exceeded the maximum number of teaching hours per week. Further, the second respondent had 44 hours in a week, while the last respondent taught 32 hours in a week.

Then, the next findings discussed respondents' other duties to do besides teaching. The four respondents almost have the same businesses. They have the same duty being a coach of English competitions, a supervisor of English organizations, and committee of school events. However, there are several different roles to do among them. The first respondent did not have responsibility to take care of students in their complex or room, while the other three respondents did. They stated that the hardest workload was actually being students' supervisor in the complex or dormitory. Besides being a teacher who is focusing on their language, the respondents also have to pay attention with students' mental physical condition. They need to take care when the students are getting sick and having problems. They mostly have a rest at midnight to control the students in the complex. They stated that the workloads of being a supervisor spent their time that made them have no time to do self-reflection to have a better teaching and enough preparation to fulfill the school administratives. Those effects significantly 
affect their teaching performance quality. The examples of the effect they mentioned were giving not optimal treatment in the class, giving too much assignment with less explanation, and improper lesson for several classes.

The last is about how they deal with the workload. The respondents agreed that the way to solve was by being professional. They stated that they could not be very good teachers who could accommodate all students' criteria, but they always tried to be responsible for their duties. They mapped about what they had to do every single day to organize busy activities.

From those three points, seven criteria to have a quality of teaching which are i) a clear objective of the lesson as well as the expected outcome, ii) building background by integrating concepts to students background, past learning and key vocabularies, iii) a clear structural idea to all students and allows them to have different pathways based on their needs, iv) using a various strategies of questioning to stimulate and encourage students' development of critical thinking, problem solving and performance skill, v) providing an adequate time for the students to give response, vi) employing instructional approaches aimed to meet the needs of diversified learners, and vii) using a well instruction to meet the proficiency level of all the students in a classroom, is not implemented very well.

Moreover, the discussion above was supported by the data obtained from the direct observation. It showed how the teachers had to spend a plenty of time to do other work outside of the school. They are being a judge in the Tuesday and Friday Performance, health care service, and parents' customer service. Those three duties had to be done by the teachers not only for the sake of the students' language improvement but also for making the students feel comfortable to stay in the dormitory.

\section{CONCLUSION}

This paper is a case study aimed at identifying the impact of Islamic boarding school teachers' workload on their teaching performance quality. Modern Islamic boarding school is a good institution implementing bilingual or multilingual programs aiming at reaching both traditional and modern education. However, there is a phenomenon which becomes a problem found in the English teachers applying that program. That is teachers' workload or intensification. Based on the findings and discussion above, it was clearly stated that having too much intensification affects negatively towards the teachers' performance quality. All of the teachers agree that their workloads become a burden for him. However, there is only one teacher who believes that the workload is a burden, but it does not affect teaching performance quality. The findings are supported by the theory about seven criteria to have a quality of teaching [21] Nonetheless, the researcher only took four teachers as the samples in this research. Finally, a further study with a broader sample and deeper observation is suggested to validate the findings making a better quality of research.

\section{REFERENCES}

[1] Selwood, I., and Pilkington, R., Teacher workload: using ICT to release time to teach, Educational Review, vol. 57, ResearchGate, 2005, pp. 163-174. DOI: https://doi.org/10.1080/0013191042000308341

[2] Lingham, G., Lingam, N., and Sharma, L., Educational reforms and implications on teachers' world of work: perspective of Fijian primary teachers, Australian Journal of Teacher Education, vol. 42, Research Online, 2017, pp. 19-35. DOI: https://doi.org/10.14221/ajte.2017v42n1.2

[3] Bell, L., and Stevenson, H., Education policy: Process, themes and impact, London: Routledge, 2006.

[4] Cardno, C., and Howse, J., The role and management development needs of secondary principals in Tonga and the Fiji Islands, International Studies in Educational Administration, vol. 33, 2005, pp. 34-44.

[5] Stevenson, H., Restructuring teachers' work and trade union responses in England: Bargaining for change, American Educational Research Journal, vol. 44, JSTOR, 2007, pp. 224-251. https://doi.org/10.3102/0002831207302194

[6] Sungalia, H., Organisations alive! Have we at least found the key to a science of educational administration, Studies in Educational Administration, vol. 52, 1990, pp. $1-32$.

[7] Wang, Pollock, and Hauseman, School principals' job satisfaction: The effects of work intensification, Canadian Journal of Educational Administration and Policy, vol. 185, ERIC, 2018, pp. 73-90.

[8] Bauer, C. S., and Brazer, D. S., The impact of isolation of the job satisfaction of new principals, Journal of School Leadership, vol. 23, SAGE Journals, 2013, pp. 152-177. DOI: https://doi.org/10.1177/105268461302300106

[9] Cenoz, J., and Gorter, D., A holistic approach to multilingual education: Introduction, The Modern Language Journal, vol. 95, ResearchGate, 2011, pp. 339- 
343. DOI: https://doi.org/10.1111/j.1540$\underline{4781.2011 .01204 . \mathrm{X}}$

[10] Baker, C., Foundations of bilingual education and bilingualism, Clevedon: Multilingual Matters, 2006.

[11] Cenoz, J., and Gorter, D., A holistic approach to multilingual education: Introduction, The Modern Language Journal, vol. 95, ResearchGate, 2011, pp. 339343. DOI: https://doi.org/10.1111/j.15404781.2011.01204.X

[12] Margana, Establishing English-Indonesian in Indonesia: from theory to practice, RA Journal of Applied Research, vol. 1, 2015, pp. 365-374. DOI: https://doi.org/10.18535/rajar/v1i10.01

[13] Baker, W. P., Lang, M., and Lawson, A. E., Classroom management for successful student inquiry, The Clearing House, vol. 75, ResearchGate, 2002, pp. 248-252.

DOI:

https://doi.org/10.1080/00098650209603949

[14] Fowler, J., and Şaraplı, O., Classroom management: What ELT students expect. Procedia Social and Behavioral Sciences, vol. 3, Elseveir, ScienceDirect, 2010, pp. 94-97. DOI: https://doi.org/10.1016/j.sbspro.2010.07.017

[15] Kaya, A., and Dönmez, B., An evaluation of the classroom management approaches of the class teachers implementing a constructivist learning approach, Procedia Social and Behavioral Sciences, vol. 1, Elseveir, ScienceDirect, 2009, pp. 575-583. DOI: https://doi.org/10.1016/j.sbspro.2009.01.104

[16] McGregor, D., Developing Thinking Developing Learning: A guide to Thinking Skills in Education, Berkshire: Open University Press, 2007.

[17] Creswell, W. John, Research Design, Third Edition, USA: Sage Publication, Inc., 2009.

[18] Bin Tahir, S. Z., Multilingual teaching and learning at pesantren schools in Indonesia, Asian EFL Journal, vol. 98, ResearchGate, 2017, pp. 74-94.

[19] Gay, L. R, Mills, G, and Airasian, P., Educational Research; Competencies for Analysis and Applications. Eight Edition, New Jersey; Pearson Prentice Hall, 2006.

[20] Creswell, W. John, Research Design, Third Edition, USA: Sage Publication, Inc., 2009.

[21] McGregor, D., Developing Thinking Developing Learning: A guide to Thinking Skills in Education, Berkshire: Open University Press, 2007. 